\title{
Optimalisasi Pemanfaatan Lahan Perkebunan Kelapa Sawit di Riau
}

\author{
Sakti Hutabarat \\ Universitas Riau \\ * shutmail@yahoo.com
}

\begin{abstract}
Abstrak. Permintaan minyak sawit yang meningkat dengan pesat sejak tahun 2000an telah direspon oleh investor dan masyarakat di Indonesia dengan membangun kebun-kebun baru. Tingkat pengetahuan masyarakat yang rendah menyebabkan peningkatan produktivitas kebun sawit dirasakan lebih sulit dibandingkan dengan membangun kebun baru. Permasalahan timbul ketika ekspansi kebun-kebun baru terjadi secara ilegal sehingga tidak terkontrol oleh pemerintah. Pengembangan kebun kelapa sawit tidak saja dilakukan di kawasan yang sesuai dan dialokasikan untuk budidaya kelapa sawit tetapi juga merambah ke kawasan hutan dan lahan gambut. Lahan mineral yang ada sebagian besar telah dikuasai oleh perusahaan-perusahaan besar sehingga pengembangan kebun-kebun baru oleh perusahaan menengah dan kecil dilakukan pada lahan-lahan gambut. Tingkat deforestasi hutan dan degradasi lahan gambut yang sangat masif menjadi isu penting pemanfaatan lahan yang berkelanjutan. Tujuan penelitian ini adalah untuk menganalisis optimalisasi pemanfaatan lahan oleh perkebunan kelapa sawit di Provinsi Riau. Studi ini dilakukan dengan menggunakan studi literature terutama dokumen-dokumen pemerintah dan hasil penelitian terdahulu. Dengan menggunakan analisis kuantitatif dan kualitatif, studi ini mengamati penggunaan lahan perkebunan kelapa sawit, faktorfaktor yang mempengaruhi ekspansi perkebunan kelapa sawit, produktivitas kebun-kebun kelapa sawit dibandingkan dengan potensi produksi, dan alternatif tindakan yang mungkin dilakukan untuk mengurangi deforestasi hutan dan degradasi lahan gambut.
\end{abstract}

Kata Kunci: kelapa sawit, optimalisasi, perkebunan, pemanfaatan lahan

\section{PENDAHULUAN}

Optimalisasi pemanfaatan lahan dan reforma agraria telah menjadi isu penting di Indonesia. Pembangunan ekonomi yang memanfaatkan lahan telah berlangsung sejak sebelum kemerdekaan Indonesia baik untuk kegiatan produksi hasil hutan, produksi komoditas perkebunan, pertambangan, dan industri lainnya. Pengurangan kawasan hutan di Indonesia semakin pesat sejak meningkatnya kegiatan ekonomi yang memanfaatkan lahan secara besar-besaran. Luas kawasan hutan di Sumatera yang pada tahun 1985 yang mencapai $85 \%$ telah berkurang drastis menjadi $36 \%$ pada tahun 2000 dan saat ini kurang dari $25 \%$ (Rumondang, 2017).

Kegiatan perkebunan merupakan salah satu pengguna lahan yang sangat masif di Indonesia terutama perkebunan kelapa sawit. Perkebunan kelapa sawit pada awalnya diusahakan oleh perusahaan negara baik Perusahaan Negara Perkebunan (PNP) maupun Perseroan Terbatas Perkebunan (PTP) pada akhir tahun 1960an (Badrun, 2010; Manggabarani, 2009b). Pada awal tahun 1970 luas perkebunan kelapa sawit mencapai 131.298 ha yang dikuasai oleh perusahaan negara 84.640 ha dan perusahaan swasta 46.658 ha. Tahun 1980 pemerintah mulai meluncurkan program Perkebunan Inti Rakyat (PIR) dengan luas perkebunan plasma mencapai 6.175 ha.

Perkembangan perkebunan kelapa sawit sangat pesat dibandingkan komoditas perkebunan utama lainnya seperti karet dan kelapa. Perkebunan kelapa sawit yang diusahakan secara komersil pada tahun 2011 pada mulanya tidak banyak mengalami perkembangan (Pahan, 2012). Demikian juga setelah Pemerintah Indonesia mulai serius mengembangkan komoditas perkebunan melalui perusahaan negara pada tahun 1970an masih belum berkembang secara signifikan (Manggabarani, 2009b). Perkembangan kelapa sawit mulai meningkat pesat menjelang tahun 2000. Permintaan minyak sawit dunia yang meningkat tajam telah memicu peningkatan harga tandan buah segar (TBS) yang pada gilirannya mendorong permintaan TBS (Badrun, 2010; Manggabarani, 2009a). 
Produsen kelapa sawit merespon tingginya permintaan TBS dengan membangun kebun-kebun baru untuk meningkatkan produksi kelapa sawit. Perkebunan Besar Swasta (PBS) merupakan produsen yang paling tanggap dalam memenuhi permintaan TBS diikuti Perkebunan Rakyat (PR) dan Perkebunan Besar Negara (PN). Kontribusi PBS dalam produksi TBS merupakan yang terbesar (52,9\%) sementara kontribusi PR mencapai 41,4\% dari total luas areal perkebunan kelapa sawit di Indonesia (Gambar 1).

Luas areal perkebunan kelapa sawit rakyat meningkat tajam setelah masyarakat di sekitar perkebunan plasma mulai menyadari keuntungan yang diperoleh dari usaha perkebunan kelapa sawit. Tingkat pendapatan kebun sawit yang relatif lebih tinggi dibandingkan komoditas tanaman pangan bahkan lebih tinggi dibandingkan komoditas perkebunan lainnya menyebabkan banyak masyarakat beralih menanam kelapa sawit (Hutabarat, 2017b). Sebagian besar masyarakat yang menanam kelapa sawit adalah masyarakat yang berpendidikan rendah yang memiliki pengetahuan yang terbatas. Pembangunan dan pemeliharaan tanaman kelapa sawit dilakukan secara tradisional tanpa bantuan dari pihak manapun. Pekebun rakyat inilah kemudian disebut Pekebun Sawit Swadaya (Rahadian, 2013). Kelompok pekebun swadaya ini berkembang dengan sangat pesat dan bersama-sama dengan pekebun plasma luas arealnya telah mencapai lebih $40 \%$ dari seluruh luas areal perkebunan sawit di Indonesia.

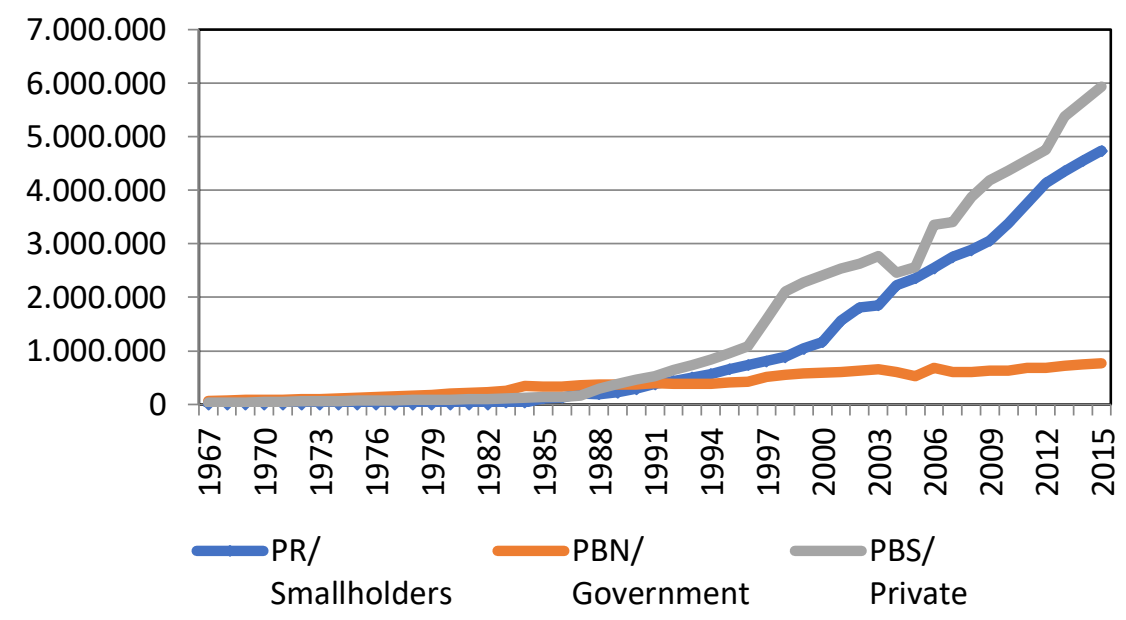

Gambar 1. Luas areal perkebunan kelapa sawit di Indonesia 1967-2015

Sektor Perkebunan Kelapa Sawit memberikan dampak positif sekaligus dampak negatif. Pembangunan perkebunan kelapa sawit diklaim memberikan manfaat kepada masyarakat dan perekonomian di Indonesia. Komoditas kelapa sawit menyediakan lapangan kerja, meningkatkan pendapatan pekebun dan masyarakat, mendorong peningkatan perekonomian di pedesaan, dan meningkatkan pendapatan nasional melalui ekspor minyak sawit. Namun, perluasan dan pembangunan kelapa sawit diklaim juga berdampak negatif. Masyarakat pada umumnya membuka, memperluas dan mengusahakan kebun sawitnya tanpa dilengkapi dokumen legalitas yang memadai sehingga perkembangan perkebunan kelapa sawit sering tidak terdokumentasi dan terkendali dengan baik. Perluasan perkebunan sawit yang tidak terkendali tidak jarang memasuki kawasan hutan sehingga menyebabkan deforestasi. Pembukaan kebun kelapa sawit juga sering dilakukan dengan cara membakar sehingga menyebabkan kebakaran lahan yang sulit diatasi dan merusak keanekaragaman hayati. Pembukaan perkebunan kelapa sawit juga berkontribusi pada kerusakan ekosistem gambut.

Produksi kelapa sawit hendaknya dapat memberikan dampak positif yang lebih besar dibandingkan dengan dampak negatif yang ditimbulkannya. Penggunaan lahan untuk perkebunan kelapa sawit diduga belum optimal. Produktivitasnya yang jauh lebih rendah dibandingkan potensi bakunya mengindikasikan penggunaan lahan yang belum optimal. Jika produktivitas dapat ditingkatkan maka penggunaan lahan dapat dioptimalkan. Kondisi inilah yang mendorong dilakukannya studi ini. Tujuan penelitian ini adalah untuk menganalisis optimalisasi pemanfaatan lahan oleh perkebunan kelapa sawit di Provinsi Riau. Penelitian ini mengamati penggunaan lahan untuk perkebunan kelapa sawit, faktor-faktor yang mempengaruhi ekspansi perkebunan, produktivitas kelapa sawit, dan alternatif tindakan optimalisasi perkebunan untuk mengurangi deforestasi hutan dan degradasi lahan gambut. 


\section{KAJIAN PUSTAKA}

Perusahaan adalah organisasi atau lembaga yang melakukan kegiatan produksi untuk mendapatkan keuntungan (profit). Produksi merupakan kegiatan mentransformasikan satu atau lebih faktor produksi (input) menjadi satu atau lebih keluaran (output). Faktor produksi adalah sumberdaya yang dipergunakan untuk kegiatan produksi seperti lahan, barang modal, energi, dan bahan baku lainnya. Keluaran (output) dapat berupa produk primer yang langsung dikonsumsi atau menjadi bahan baku untuk diolah lebih lanjut oleh manufaktur. Faktor produksi tidak tetap (variabel) adalah faktor produksi yang jumlah penggunaannya bervariasi sesuai jumlah yang akan diproduksi sedangkan faktor produksi tetap adalah faktor produksi yang dalam jangka pendek tidak dapat dengan mudah dirubah volumenya tetapi dapat berubah kuantitasnya dalam jangka panjang. Menurut teori produksi neoklasik, produsen individual adalah rasional dan memaksimumkan keuntungan mereka, ceteris paribus teknologi, harga faktor produksi, dan harga produk (Henderson \& Quandt, 1980).

Lahan adalah salah satu faktor produksi tetap yang dibutuhkan dalam produksi buah sawit. Lahan harus tersedia dalam kuantitas (unit) yang sama dalam satu siklus produksi atau minimal 25 tahun. Lahan memiliki biaya oportunitas yang bervariasi sesuai dengan peluang produksi dan pasar yang tersedia dan memiliki kelayakan ekonomi. Penggunaan lahan yang tidak memberikan rate of return yang layak menyebabkan pemanfaatannya tidak optimal (Umar, 2003).

Dalam era industri 3.0 dan 4.0, produksi suatu barang dan jasa tidak saja harus memperhatikan penggunaan kombinasi faktor produksi yang efisien (aspek teknis dan aspek ekonomis) namun juga wajib memperhatikan aspek sosial dan aspek lingkungan. Pertanian berkelanjutan atau "sustainable agriculture" merupakan suatu konsep yang harus diaplikasikan oleh setiap aktor yang terlibat di rantai pasok produksi minyak sawit dan produk-produk turunannya (Komisi ISPO, 2014; RSPO, 2007).

Sustainable Agriculture antara lain ditandai dengan sertifikasi yang mempresentasikan kepatuhan produsen and aktor-aktor pada rantai pasok produk tertentu kepada prinsip dan kriteria keberlanjutan dalam praktek produksi pertanian. Sertifikasi dikeluarkan oleh lembaga-lembaga sertifikasi baik pemerintah maupun swasta. Indonesian Sustainable Palm Oil (ISPO) merupakan sertifikasi produk kelapa sawit yang diwajibkan bagi produsen kelapa sawit yang beroperasi di Indonesia sedangkan Roundtable on Sustainable Palm Oil (RSPO) adalah sertifikat untuk produk-produk minyak sawit dan produk turunannya yang dipasarkan ke Uni Eropa atau di pasar international lainnya. Sertifikasi tersebut pada umumnya adalah upaya untuk mendorong agar produksi minyak sawit dilakukan secara lestari dan berkelanjutan (Hutabarat et al., 2017).

Penggunaan faktor produksi lahan yang optimal merupakan salah satu isu yang penting dalam mengurangi dampak negatif usaha perkebunan kelapa sawit terutama deforestasi dan hilangnya keragaman hayati. Penggunaan kombinasi faktor produksi (bibit unggul, pupuk yang tepat (jenis, dosis, waktu, dan cara), tenaga kerja terampil, dan lain-lain) yang efisien diharapkan dapat menghasilkan produktivitas per hektar yang tinggi sehingga penggunaan lahan dapat dioptimalkan. Optimalisasi penggunaan lahan pada gilirannya akan menghindarkan ekspansi ke kawasan hutan yang dilindungi dan lahan gambut (Hidayat et al., 2016; Molenaar et al., 2010).

\section{METODE}

Studi ini dilakukan di Provinsi Riau dengan pertimbangan provinsi ini merupakan penghasil terbesar minyak sawit di Indonesia dan menghadapi cukup banyak persoalan terkait penggunaan lahan. Kajian ini dilakukan dengan menggunakan studi literatur dan dokumen-dokumen yang tersedia di lembaga-lembaga pemerintah maupun swasta. Penggunaan data-data primer dari studi terdahulu di wilayah Kabupaten Pelalawan, Siak, Bengkalis, dan Rokan Hulu sangat mendukung analisis untuk menggambarkan kondisi nyata di lapangan. Data primer mencakup karakteristik pekebun, penggunaan faktor produksi, praktek budidaya, manajemen kebun, sistem pemasaran dan organisasi pekebun. Untuk melengkapi kajian ini dengan data kualitatif dilakukan juga kunjungan ke perkebunan dan wawancara dengan beberapa stakeholder perkebunan seperti koperasi (KUD), kelompok pekebun (Poktan/Gapoktan), Manajemen Perusahaan Perkebunan dan Pabrik Kelapa Sawit (PKS), Dinas Perkebunan, Pedagang Perantara, dan Lembaga Swadaya Masyarakat (LSM). 


\section{HASIL DAN PEMBAHASAN}

\section{Gambaran Umum Provinsi Riau}

Provinsi Riau memiliki luas $107.931,71 \mathrm{~km} 2$ atau $8.915 .015,09$ ha terdiri dari $86.411,90 \mathrm{~km} 2$ daratan dan $21.478,81 \mathrm{~km} 2$ dengan panjang garis pantai $2.078,15 \mathrm{~km}$. Wilayah administrasi di Provinsi Riau terdiri dari 10 kabupaten, 2 kota, 164 kecamatan, 1.836 desa/kelurahan/kepenghuluan, dan 76 pulau. Jumlah penduduk di Provinsi Riau sebanyak 6.188.400 jiwa terdiri dari 3.178.400 jiwa laki-laki dan 3.010.000 jiwa perempuan (Ernaputra, 2017). Potensi daratan yang luas telah dimanfaatkan untuk berbagai kegiatan ekonomi yang menyediakan lapangan pekerjaan sekaligus sumber pendapatan penduduk. Namun sebagian lahan yang tersedia di Provinsi Riau dimanfaatkan untuk kegiatan perkebunan, pertambangan dan industri oleh investor luar.

Tabel 1. Data Geografis dan Demografi Provinsi Riau Tahun 2017

\begin{tabular}{|c|c|c|c|c|c|}
\hline & $\begin{array}{l}\text { Luas } \\
\text { (ha) }\end{array}$ & Pulau & Kecamatan & Desa/Kel & $\begin{array}{l}\text { Jumlah Penduduk } \\
\text { (jiwa) }\end{array}$ \\
\hline \multicolumn{6}{|l|}{ Kawasan Daratan } \\
\hline Kab Rokan Hulu & $722.977,68$ & & 16 & 153 & 543.857 \\
\hline Kab Kampar & $1.092 .819,71$ & & 21 & 245 & 766.351 \\
\hline Kab Kuansing & $520.216,13$ & & 15 & 229 & 317.265 \\
\hline Kab Indragiri Hulu & $767.626,66$ & & 14 & 194 & 401.207 \\
\hline Kota Pekanbaru & $63.300,86$ & & 12 & 58 & 999.031 \\
\hline \multicolumn{6}{|l|}{ Kawasan Pesisir } \\
\hline Kab Rokan Hilir & $896.142,93$ & 30 & 16 & 183 & 618.355 \\
\hline Kab Bengkalis & $843.720,05$ & 4 & 8 & 155 & 543.786 \\
\hline Kab Siak & $823.357,00$ & 1 & 14 & 131 & 421.477 \\
\hline Kab Kep Meranti & $360.703,00$ & 9 & 9 & 101 & 183.912 \\
\hline Kab Indragiri Hilir & $1.379 .837,12$ & 32 & 20 & 236 & 697.814 \\
\hline Kab Pelalawan & $1.240 .413,95$ & & 12 & 118 & 352.207 \\
\hline \multirow[t]{2}{*}{ Kota Dumai } & $203.900,00$ & & 7 & 33 & 280.027 \\
\hline & $8.915 .015,09$ & 76,00 & 164,00 & $1.836,00$ & $6.125 .289,00$ \\
\hline
\end{tabular}

Sumber: Dinas Tanaman Pangan Hortikultura dan Perkebunan Provinsi Riau (2017).

Tabel 2. Tata Ruang Provinsi Riau Tahun 2010 (Perda No.10/1994)

\begin{tabular}{|c|c|c|}
\hline Kawasan & Luas (ha) & Persentase \\
\hline Perkebunan & $3.300 .767,54$ & $78,54 \%$ \\
\hline Pertanian & $602.677,19$ & $14,34 \%$ \\
\hline Pariwisata & $3.261,19$ & $0,08 \%$ \\
\hline Industri & $21.782,66$ & $0,08 \%$ \\
\hline Pertambangan & $54.197,55$ & $1,29 \%$ \\
\hline Pemukiman & $77.878,52$ & $1,85 \%$ \\
\hline \multirow[t]{2}{*}{ Lainnya (sungai, danau) } & $142.254,84$ & $3,38 \%$ \\
\hline & $4.202 .819,49$ & $100,00 \%$ \\
\hline
\end{tabular}

Sumber: Dinas Tanaman Pangan Hortikultura dan Perkebunan Provinsi Riau (2017)

Berdasarkan Perda No.10 tahun 1994 tentang Rencana Tata Ruang Provinsi Riau luas daratan Provinsi Riau mencapai 8.975.784,66 ha yang terdiri dari 4.772.956.17 ha $(53,17 \%)$ kawasan hutan dan 4.202.828,49 ha $(46,82 \%)$ kawasan non-hutan. Berdasarkan Perda tersebut, pemanfaatan kawasan non-hutan di Provinsi Riau terdiri dari tujuh kawasan dimana kawasan perkebunan merupakan yang terluas disusul oleh kawasan pertanian. Posisi sektor perkebunan dan pertanian sangat penting bagi perekonomian di Provinsi Riau (Tabel 2). Semakin meningkatnya permintaan minyak sawit dunia sangat memungkinkan terjadi ekspansi perkebunan sawit yang lebih luas lagi dari areal yang disediakan dan kondisi ini tidak tercatat karena 
sebagian besar pekebun rakyat dan perusahaan perkebunan skala kecil dan menengah tidak pernah mendaftarkan keberadaan perkebunannya.

Pemanfaatan kawasan hutan di Provinsi Riau terdiri dari Kawasan Suaka Alam (KSA)/Kawasan Pelestarian Alam (KPA), Hutan Lindung (HL), Hutan Produksi Terbatas (HPT), Hutan Produksi Tetap (PH), dan Hutan Produksi Konversi (HPK). Areal hutan yang telah dilepas untuk penggunaan di luar produksi hutan dikategorikan sebagai Areal Penggunaan Lain (APL). Luas kawasan hutan di Provinsi Riau telah direvisi beberapa kali untuk mengakomodasi kegiatan ekonomi yang membutuhkan lahan. Akibatnya luas kawasan hutan terus menyusut dari tahun ke tahun. Pada tahun 2016, Hutan Produksi Tetap mencapai 2,3 juta ha $(25,9 \%)$ dan Hutan Produksi Konversi 1,18 juta ha $(13,2 \%)$ sementara Areal Penggunaan Lain telah mencapai 3,4 juta ha (Tabel 3).

Berdasarkan pengamatan di lapangan, luas kawasan hutan telah menurun jauh lebih rendah dari data resmi pemerintah. Kondisi ini disebabkan masih banyaknya pelaku usaha kehutanan dan perkebunan yang tidak memiliki izin usaha dan tidak terdaftar secara resmi sehingga kegiatan usahanya tidak tercatat dan tidak terdeteksi oleh Pemerintah. Penggunaan lahan secara tidak ilegal tersebut sebenarnya sudah diidentifikasi oleh Pemerintah. Namun tindakan hukum terhadap pelaku ilegal bisnis tersebut masih belum diterapkan dengan tegas.

Tabel 3. Luas Kawasan Hutan di Provinsi Riau Tahun 2016

\begin{tabular}{clcrr}
\hline No. & \multicolumn{1}{c}{ Fungsi Kawasan } & Code & \multicolumn{1}{c}{ Luas (ha) } & \multicolumn{1}{c}{$\%$} \\
\hline 1 & Kawasan Suaka Alam/ & SM, CA, HW, TN, & 630.753 & 7,00 \\
& Kawasan Pelestarian Alam & TAHURA, PLG, TWA & & \\
2 & Hutan Lindung & HL & 233.910 & 2,59 \\
3 & Hutan Produksi Terbatas & HPT & 1.017 .318 & 11,28 \\
4 & Hutan Produksi Tetap & PH & 2.339 .578 & 25,95 \\
5 & Hutan Produksi Konversi & HPK & 1.185 .433 & 13,15 \\
\hline & Subtotal KH & & $\mathbf{5 . 4 0 6 . 9 9 2}$ & $\mathbf{5 9 , 9 7}$ \\
\hline 6 & Areal Penggunaan Lain & APL & 3.489 .800 & 38,71 \\
7 & Perairan & AIR & 119.609 & 1,33 \\
\hline & Total & & $\mathbf{9 . 0 1 6 . 4 0 1}$ & $\mathbf{1 0 0 , 0 0}$ \\
\hline
\end{tabular}

Sumber: SK MenLHK No.903/MenLHK/Setjen/PLA.2/12/2016

\section{Pengembangan Perkebunan di Provinsi Riau}

Komoditas perkebunan telah cukup lama diusahakan oleh masyarakat di Provinsi Riau. Kelapa dan karet merupakan komoditas tradisional di wilayah ini. Sejak tahun 1980an, tanaman kelapa sawit mulai dikembangkan dengan serius oleh perusahaan besar dan menengah yang kemudian diikuti oleh masyarakat di sekitar perusahaan perkebunan. Permintaan minyak sawit dunia yang meningkat pesat sejak tahun 2000an dengan harga TBS yang selalu meningkat merupakan faktor pendorong pembangunan kebun-kebun kelapa sawit yang baru. Pada tahun 2015 luas perkebunan kelapa sawit telah mencapai 11,4 juta ton dengan produksi CPO 31,3 juta ton dimana kontribusi Provinsi Riau mencapai 2,4 juta ha (24\%) dengan produksi minyak sawit 7,8 ton CPO (27\%), (Tabel 4).

Tabel 4. Luas Perkebunan di Provinsi Riau Tahun 2015

\begin{tabular}{lrrrrrr}
\hline \multicolumn{1}{c}{ Komoditi } & \multicolumn{1}{c}{$\begin{array}{c}\text { Luas } \\
\text { (ha) }\end{array}$} & $\begin{array}{c}\text { Produksi } \\
\text { (Ton) }\end{array}$ & $\begin{array}{c}\text { Peringkat } \\
\text { Nasional }\end{array}$ & $\begin{array}{c}\text { Jumlah } \\
\text { Pekebun } \\
\text { (KK) }\end{array}$ & $\begin{array}{c}\text { Jumlah orang } \\
\text { Tertanggung } \\
\text { (Jiwa) }\end{array}$ & Kepemilikan \\
\hline Kelapa Sawit & 2.424 .544 & 7.841 .947 & No. 1 & 524.561 & 2.098 .244 & $53 \%$ rakyat \\
Kelapa & 514.167 & 321.465 & No. 1 & 208.065 & 832.260 & $97 \%$ rakyat \\
Karet & 501.787 & 374.900 & No. 4 & 241.071 & 964.284 & $98 \%$ rakyat \\
Sagu & 83.691 & 366.032 & No. 1 & 12.562 & 50.248 & $80 \%$ rakyat \\
Lain-lain & 26.022 & & & 73.203 & 292.812 & $95 \%$ rakyat \\
\hline Jumlah & 3.550 .211 & 8.904 .344 & & 1.059 .462 & 4.237 .848 & \\
\hline
\end{tabular}

Sumber: Dinas Tanaman Pangan Hortikultura dan Perkebunan Provinsi Riau (2017) 
Perkebunan merupakan sektor ekonomi yang menyediakan banyak lapangan kerja bagi masyarakat di Provinsi Riau. Keterlibatan masyarakat dalam sektor perkebunan mencapai lebih dari $80 \%$ di setiap komoditasnya. Sebagai tanaman tradisional perkebunan merupakan sumber mata pencaharian utama bagi sebagian besar masyarakat di Provinsi Riau. Namun sebelum diperkenalkannya kelapa sawit, perkebunan karet dan kelapa sangat dominan di provinsi ini. Peran Sektor Perkebunan di Provinsi Riau dapat dilihat dari jumlah pekebun yang terlibat di sektor ini. Sektor Perkebunan merupakan sumber mata pencaharian lebih dari satu juta rumah tangga pekebun dengan jumlah orang yang tertanggung lebih dari 4 juta jiwa. Dengan kata lain, lebih dari 64\% penduduk di Provinsi Riau menggantungkan hidupnya dari Sektor Perkebunan.

Sektor Perkebunan sangat berperan dalam meningkatkan perekonomian masyarakat di pedesaan dan di tingkat nasional. Kontribusi Sektor Perkebunan terhadap PDRB Provinsi Riau 86 Triliun atau 12,5\% dari total PDRB Provinsi Riau (682,3 triliun) tahun 2015. Kontribusi Perkebunan dalam Sektor Pertanian mencapai $59 \%$.

\section{Pengembangan Perkebunan Kelapa Sawit}

Perkebunan kelapa sawit merupakan komoditas primadona di Provinsi Riau. Tanaman ini diperkenalkan melalui perusahaan perkebunan negara baik Perusahaan Negara Perkebunan (PNP) maupun Perseroan Terbatas Perkebunan (PTP) yang pada saat ini melebur menjadi PT Perkebunan Nusantara. Tanaman kelapa sawit juga diperkenalkan kepada masyarakat melalui pembangunan kebun-kebun plasma yang bermitra dengan perusahan besar negara maupun swasta. Pertumbuhan perkebunan kelapa sawit yang semula berjalan lambat selama tahun 1980an kemudian meningkat pesat dengan meningkatnya permintaaan minyak sawit dan harga tandan buah segar (TBS) sejak menjelang tahun 2000an. Produsen kelapa sawit merespon peningkatan permintaan minyak sawit dengan meningkatkan produksi TBS melalui perluasan kebun kelapa sawit dinilai lebih mudah dilaksanakan daripada meningkatkan produktivitas kebun yang telah ada (Hutabarat, 2017b). Luas perkebunan kelapa sawit selalu mengalami peningkatan selama dua dekade terakhir terutama pada Perkebunan Besar Swasta dan Perkebunan Rakyat (Gambar 2).

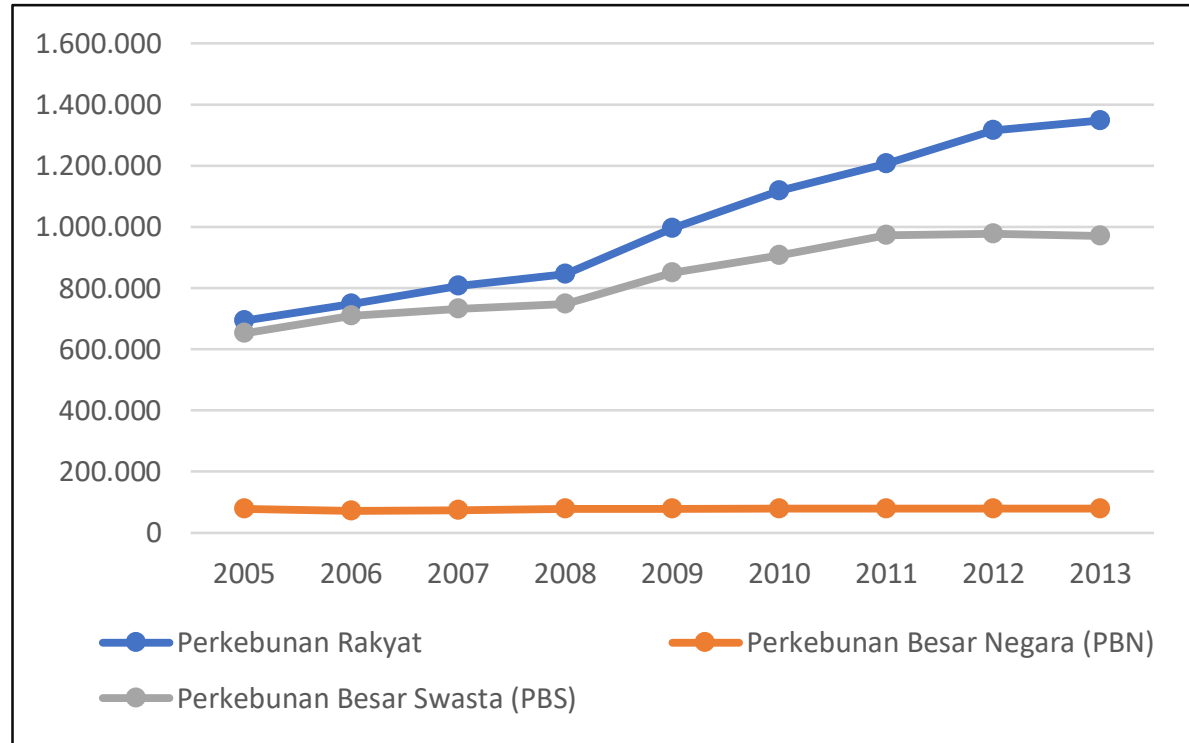

Gambar 2. Luas Perkebunan Kelapa Sawit di Provinsi Riau Tahun 2015

Pada tahun 2000an pembangunan kebun-kebun baru sangat pesat dilakukan oleh Perusahaan Besar Swasta maupun Pekebun Rakyat (Gambar 2). Komoditas kelapa sawit yang dinilai berhasil meningkatkan pendapatan negara maupun pendapatan petani kemudian didorong oleh Pemerintah dengan program revitalisasi perkebunan kelapa sawit melalui Permentan No.33/2006 tentang Pembangunan Perkebunan Melalui Program Revitalisasi Perkebunan.

Kelapa sawit merupakan sektor pendorong (leading sector) yang paling dirasakan dampaknya bagi pembangunan ekonomi baik di Provinsi Riau maupun Indonesia. Meskipun keterlibatan masyarakat hanya $53 \%$ namun sektor ini melibatkan jumlah pekebun yang sangat besar (524.561 KK) dengan jumlah orang tertanggung lebih dari dua juta jiwa, sementara di tingkat nasional jumlah pekebun mencapai 2,2 juta KK dengan jumlah orang yang bergantung pada sektor ini lebih dari 16 juta orang (Rumondang, 2017). 
Perluasan perkebunan kelapa sawit dilakukan secara masif dan sebagian besar tidak dilengkapi dengan dokumen legalitas yang memadai sehingga pengembangannya tidak terkendali. Akibatnya tidak sedikit kawasan hutan yang dirambah untuk membuka kebun-kebun sawit yang baru (Hutabarat, 2017b). Dampaknya tidak saja pada deforestasi yang sangat parah plus kebakaran hutan yang meluas akibat pembukaan lahan dengan cara dibakar. Kondisi inilah yang menjadi perhatian produsen dan konsumen minyak sawit dunia yang mengkritisi produksi minyak sawit yang tidak berkelanjutan. Isu deforestasi, kebakaran hutan, hilangnya keanekaragaman hayati, emisi gas rumah kaca, dan konflik sosial menjadi sorotan dunia internasional.

Permasalahan legalitas tidak saja dihadapi oleh pekebun rakyat namun juga dijumpai pada perusahaan perkebunan berskala menengah dan besar. Hasil Penelitian Idsert Jelsma (2016) memperlihatkan luas perkebunan berskala menengah dan kecil cukup besar dan sebagian daripadanya belum memiliki legalitas yang disyaratkan (Jelsma \& Schoneveld, 2016).

\section{Pemanfaatan Lahan Gambut untuk Perkebunan Kelapa Sawit}

Luas lahan gambut di Provinsi Riau mencapai 4,03 juta ha atau 56\% dari luas daratan Provinsi Riau (8.915.015,09 ha). Hampir seluruh kabupaten/kota memiliki areal bergambut. Indragiri Hilir merupakan kabupaten yang memiliki lahan gambut yang terluas disusul oleh Bengkalis, Pelalawan, dan Siak (BKSDA Riau, 2014). Dengan porsi gambut yang lebih dari setengah luas daratan dan areal perkebunan memiliki porsi yang terbesar dalam RTRW Provinsi Riau maka dapat dipastikan sebagian dari areal perkebunan berada di kawasan lahan gambut (Tabel 5).

Tabel 5. Jenis Penggunaan Lahan Gambut per Kabupaten/Kota di Provinsi Riau Tahun 2017

\begin{tabular}{|c|c|c|c|c|c|c|c|c|}
\hline \multirow{3}{*}{ Kabupaten } & \multicolumn{7}{|c|}{ Jenis Penggunaan Lahan Gambut (ha) } & \multirow[t]{3}{*}{ Total } \\
\hline & \multicolumn{3}{|c|}{ Hutan } & \multirow{2}{*}{ Perkebunan } & \multicolumn{3}{|c|}{ Tanaman Pangan } & \\
\hline & $\mathrm{HP}$ & HS & HTI & & Sawah & Ladang & LKS & \\
\hline Bengkalis & 115.287 & 58.814 & 3.898 & 182.823 & 5.338 & 5.089 & 5.186 & 376.435 \\
\hline Kep Meranti & 2.163 & 66.073 & 4.470 & 65.965 & 643 & 1.160 & 15.586 & 156.060 \\
\hline Pekanbaru & 0 & 0 & 0 & 0 & 0 & 810 & 1.542 & 2.352 \\
\hline Dumai & 3.915 & 30.254 & 1.324 & 15.870 & 4 & 162 & 8.972 & 60.501 \\
\hline Siak & 54.002 & 57.838 & 50.465 & 93.756 & 4.624 & 4.183 & 11.650 & 276.518 \\
\hline Rokan Hulu & 0 & 3.702 & 0 & 18.298 & 0 & 362 & 1.264 & 23.626 \\
\hline Rokan Hilir & 803 & 48.622 & 7.220 & 129.397 & 0 & 9.645 & 67.105 & 262.792 \\
\hline Pelalawan & 122.076 & 114.965 & 90.763 & 100.825 & 5.738 & 3.678 & 20.718 & 458.763 \\
\hline Kuantan & & & & & & & & \\
\hline Sengingi & 0 & 0 & 0 & 0 & 0 & 0 & 0 & 0 \\
\hline Kampar & 0 & 3.759 & 1.930 & 88.137 & 0 & 0 & 11.432 & 105.258 \\
\hline Indragiri Hulu & 29.561 & 53.463 & 8.446 & 19.892 & 0 & 12.299 & 0 & 123.661 \\
\hline Indragiri Hilir & 7.546 & 101.894 & 9.747 & 626.105 & 116.570 & 34.822 & 41.160 & 937.844 \\
\hline Riau & 335.353 & 539.384 & 178.263 & 1.341 .068 & 132.917 & 72.210 & 184.615 & 2.783 .810 \\
\hline
\end{tabular}

Sumber: Dinas Lingkungan Hidup dan Kehutanan Provinsi Riau (2017)

Pemanfaatan lahan gambut tidak dapat dihindari ketika perluasan kebun sawit tidak lagi menemukan tanah mineral yang sesuai untuk budidaya kelapa sawit. Para investor, masyarakat dan juga pemerintah mengklaim bahwa industri kelapa sawit memberikan dampak positif bagi pertumbuhan ekonomi dan kesejahteraan masyarakat. Namun dampak negatif dari kegiatan perkebunan kelapa sawit belum teratasi dengan baik (Hutabarat, 2018b).

Pemerintah Indonesia telah menerbitkan berbagai aturan perundangan untuk membatasi penggunaan lahan gambut untuk budidaya kelapa sawit seperti Permentan No.14/2009 tentang Pedoman Pemanfaatan Lahan Gambut untuk Budidaya Kelapa Sawit dan PP No.57/2016 tentang Perlindungan dan Pengelolaan Ekosistem Gambut. Kenyataannya tidak sedikit area gambut yang digunakan untuk kegiatan komersial (kehutanan dan perkebunan) baik pada area budidaya maupun area lindung. Bahkan penggunaan lahan gambut dilakukan tanpa adanya izin resmi pemerintah (Tabel 6). 
Peraturan yang diterbitkan oleh Pemerintah tidak jarang bertentangan antara satu aturan dengan aturan lainnya. Penerapan aturan Pemerintah juga kurang memperhatikan kondisi di lapangan dimana suatu aturan dapat membatalkan kegiatan investasi yang telah menelan biaya cukup besar. Akibatnya, tidak sedikit investor yang mengabaikan peraturan pemerintah meskipun dengan resiko hukum yang akan dihadapinya. Investor tidak mungkin mengikuti aturan pemerintah tanpa resiko merugi. Kebijakan Pemerintah yang berbeda dengan kebijakan sebelumnya tidak jarang menyebabkan kondisi investasi yang tidak menarik.

Tabel 6. Luas Penggunaan Lahan Gambut di Provinsi Riau (ha)

\begin{tabular}{|c|c|c|c|c|c|c|c|}
\hline \multirow{3}{*}{$\begin{array}{l}\text { Kabupaten/ } \\
\text { Kota }\end{array}$} & \multicolumn{6}{|c|}{ Luas Penggunaan Pada Lahan Gambut (Ha) } & \multirow{3}{*}{ Total } \\
\hline & \multicolumn{3}{|c|}{ Area Lindung } & \multicolumn{3}{|c|}{ Area Budidaya } & \\
\hline & Berizin & $\begin{array}{c}\text { Tidak } \\
\text { Berizin*) }\end{array}$ & Subtotal & Berizin & $\begin{array}{c}\text { Tidak } \\
\text { Berizin*) }\end{array}$ & Subtotal & \\
\hline Bengkalis & 2.347 & 18.692 & 21.040 & 30.759 & 173.790 & 204.549 & 225.589 \\
\hline Dumai & 74 & 3.342 & 3.416 & & 45.917 & 45.917 & 49.332 \\
\hline Indragiri Hilir & 48.757 & 52.374 & 101.131 & 139.210 & 351.093 & 490.303 & 591.434 \\
\hline Indragiri Hulu & 1.359 & 628 & 1.987 & 24.430 & 19.802 & 44.232 & 46.219 \\
\hline Kampar & 7.333 & 12.454 & 19.786 & 82.036 & 125.885 & 207.921 & 227.707 \\
\hline Kep Meranti & & 20.435 & 20.435 & & 79.582 & 79.582 & 100.016 \\
\hline Pekanbaru & 0 & 0 & 0 & 6.421 & 30.502 & 36.923 & 36.923 \\
\hline Pelalawan & 9.498 & 3.380 & 12.878 & 50.403 & 70.532 & 120.935 & 133.813 \\
\hline Rokan Hilir & 6.403 & 45.633 & 52.036 & 56.634 & 248.383 & 305.018 & 357.053 \\
\hline Rokan Hulu & 2.691 & 2.354 & 5.045 & 9.694 & 15.126 & 24.820 & 29.866 \\
\hline Siak & 14.148 & 24.108 & 38.256 & 69.525 & 131.683 & 201.208 & 239.464 \\
\hline Kuantan Sengingi & - & - & - & - & - & - & \\
\hline Total & 92.610 & 183.400 & 276.010 & 469.114 & 1.292 .293 & 1.761 .407 & 2.037 .417 \\
\hline
\end{tabular}

Sumber: Dinas Lingkungan Hidup dan Kehutanan Provinsi Riau (2017)

\section{Tata Kelola Perkebunan dan Produktivitas Kelapa Sawit}

Pengelolaan perkebunan kelapa sawit dilakukan secara lebih intensif pada perkebunan berskala besar sedangkan pada perkebunan berskala menengah dan kecil serta perkebunan rakyat lebih banyak dikelola dengan praktek budidaya yang masih tradisional. Pengetahuan akan tata kelola perkebunan dan budidaya kelapa sawit yang baik belum dimiliki secara memadai oleh pengusaha dan pekebun. Penggunaan bibit unggul masih kurang optimal baik disebabkan akses yang sulit untuk mendapatkan bibit unggul maupun pengetahuan akan manfaat penggunaan bibit unggul. Praktek-praktek budidaya yang baik belum diterapkan. Pemeliharaan tanaman seperti pembersihan piringan dan blok tanaman tidak dilakukan dengan optimal. Manajemen tajuk juga kurang diperhatikan karena pekebun tidak mengetahui manfaat pemangkasan yang berkaitan dengan produksi buah sawit. Pemupukan tidak dilakukan dengan jenis, dosis, waktu dan tempat yang tepat sehingga tidak efektif dan tidak efisien. Pemanenan dilakukan tanpa memperhatikan tingkat kematangan buah, buah yang busuk dan rusak, pengumpulan berondolan, dan transportasi dari kebun ke pabrik kelapa sawit.

Praktek budidaya kelapa sawit yang dilakukan secara tradisional mengakibatkan produktivitas tanaman kelapa sawitnya rendah. Penelitian yang dilakukan Lee et al. (2014) dan (Hutabarat et al., 2018) menyebutkan produktivitas perkebunan rakyat rata-rata 12-14 ton/ha/tahun lebih rendah dari kebun plasma yang rata-rata 20-22 ton/ha/tahun. Produktivitas kelapa sawit pada perusahan perkebunan mencapai 20-24 ton/ha/tahun. Dibandingkan dengan potensi bibit unggul yang mampu menghasilkan 28-34 ton/ha/tahun maka produktivitas perkebunan kelapa sawit masih sangat rendah. Jika kita mampu menghasilkan produktivitas sesuai dengan potensi bibit unggul maka kita dapat mengurangi penggunaan lahan untuk produksi kelapa sawit dengan hanya menggunakan setengah dari luas areal areal yang ada saat ini (Fairhurst, 2003; Molenaar et al., 2010).

\section{Strategi Optimalisasi Penggunaan Lahan}

Penggunaan lahan untuk perkebunan kelapa sawit dilakukan dengan sangat masif untuk memenuhi permintaan minyak sawit yang meningkat tajam baik di pasar domestik maupun di pasar internasional. Ekspansi kebun kelapa sawit yang semula dilakukan di lahan mineral kemudian dilanjutkan pada lahan gambut karena keterbatasan ketersediaan lahan mineral.

Luas lahan mineral di Provinsi Riau diperkirakan kurang dari setengah luas daratan. Sebagian lahan mineral tersebut terdapat di kawasan hutan dan sebagian lagi sudah dilepas sebagai Areal Penggunaan Lain 
(APL) untuk budidaya tanaman selain hutan. Demikian juga lahan gambut memiliki luas lebih $50 \%$ dari luas daratan di Provinsi Riau. Pemanfaatan lahan gambut menjadi alternatif yang tidak bisa dielakkan di tengah tingginya permintaan minyak sawit dan buah sawit.

Luas perkebunan kelapa sawit yang telah melebihi luas areal yang sesuai dan dialokasikan untuk budidaya kelapa sawit mengindikasikan bahwa sebagian dari perkebunan kelapa sawit tersebut telah menduduki kawasan hutan dan/atau kawasan lahan gambut. Dari data ketersediaan lahan untuk budidaya kelapa sawit yang dialokasikan 9,7 juta hektar sementara luas perkebunan kelapa sawit telah mencapai 11,9 juta hektar maka terdapat sekitar 2,2 juta hektar perkebunan kelapa sawit yang patut diduga berada di kawasan hutan dan/atau kawasan gambut (Gambar 3).

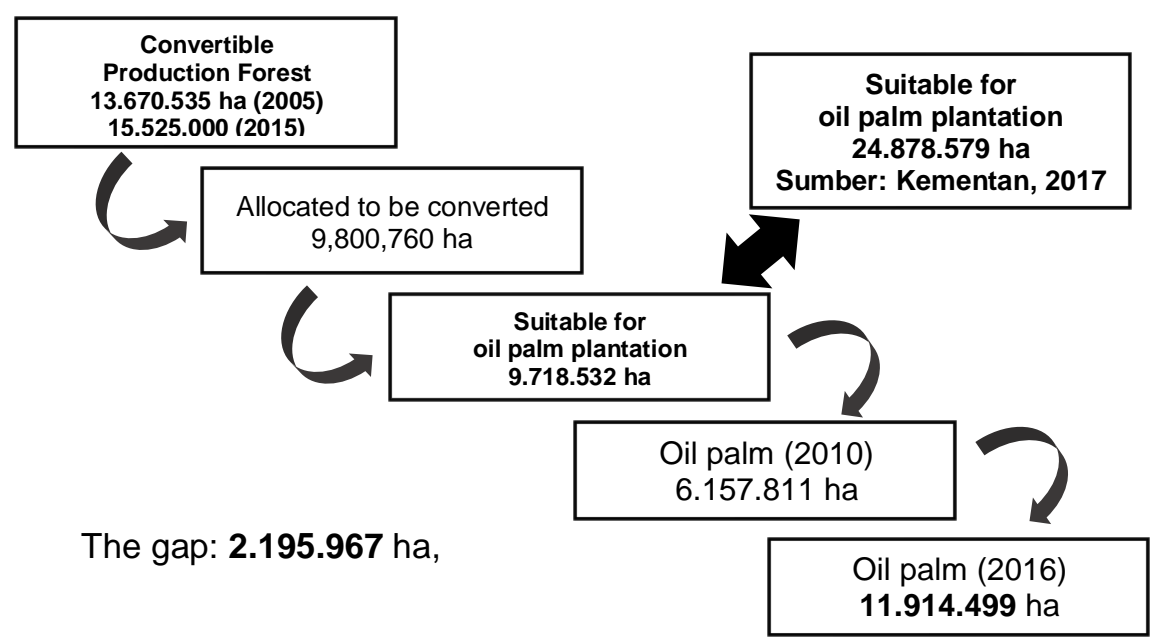

Sumber: PPKS Marihat (2004) dan Directorate General of Estate Crop (2015)

Gambar 3. Alokasi lahan dan luas perkebunan kelapa sawit di Indonesia

Selama lima tahun terakhir terjadi perubahan yang sangat signifikan pada data perkebunan kelapa sawit di Indonesia. Lahan yang dialokasikan untuk perkebunan kelapa sawit meningkat tajam. Data Kementerian Pertanian mencatat 24,9 juta hektar lahan telah dialokasikan untuk perkebunan kelapa sawit tahun 2017. Kondisi ini memperlihatkan sikap permisif dari Pemerintah Indonesia dalam pemanfaatan lahan untuk budidaya kelapa sawit yang telah diperkuat dengan diterbitkannya Permentan No. 33/2006 tentang Revitalisasi Perkebunan Kelapa Sawit. Penambahan alokasi lahan untuk perkebunan kelapa sawit mengindikasikan betapa kuatnya kepentingan bisnis minyak sawit dibandingkan lingkungan hidup seperti kawasan hutan, keragaman hayati, dan ekosistem gambut.

Perkebunan kelapa sawit telah terlanjur menduduki kawasan hutan (A), kawasan gambut (C), dan gabungan keduanya (D). Strategi untuk mengoptimalkan penggunaan lahan untuk budidaya sawit dapat dilakukan dengan tiga tahap: Pertama, menghentikan ekspansi kebun kelapa sawit ke kawasan hutan dan gambut (Gambar 4b); kedua, menghentikan penggunaan kawasan hutan dan gambut yang terlanjur digunakan untuk kebun kelapa sawit (Gambar 4c); ketiga, merestorasi ekosistem kawasan hutan dan lahan gambut yang terlanjur digunakan untuk perkebunan kelapa sawit; dan keempat, meningkatkan produktivitas kebun kelapa sawit di perkebunan kelapa sawit yang telah dialokasikan sesuai peruntukannya. 


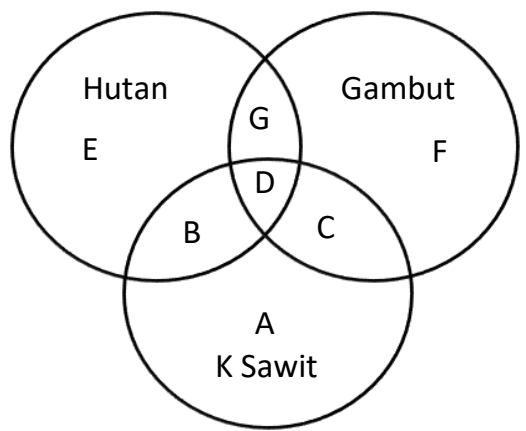

(a)

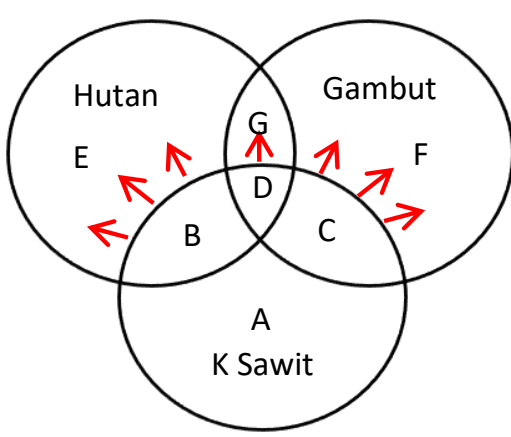

(b)

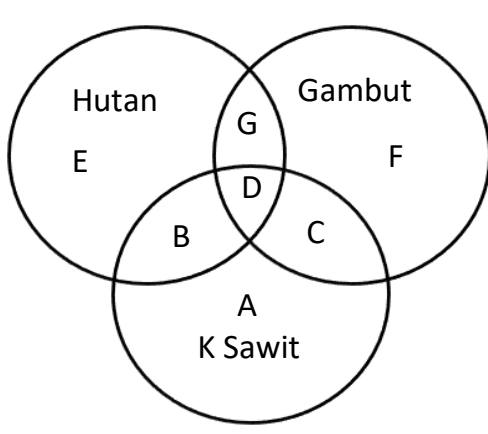

(d)

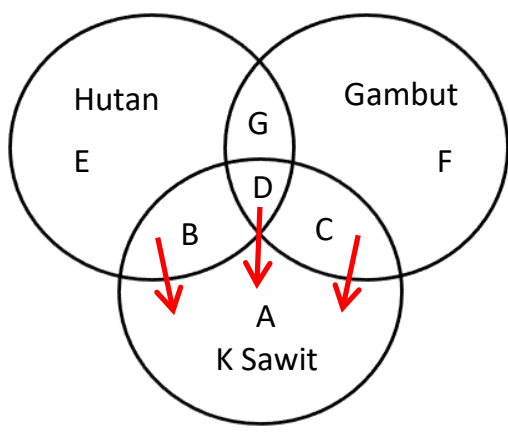

(c)

Sumber: Hutabarat (2018b)

Gambar 4. Optimalisasi Pemanfaatan Lahan untuk Kelapa Sawit

\section{Kebijakan Pemerintah}

Strategi untuk mengoptimalkan penggunaan lahan untuk perkebunan kelapa sawit dapat dilakukan dengan dukungan kebijakan pemerintah dan swasta (Hutabarat, 2018b). Pertama, untuk menghindari ekspansi perkebunan kelapa sawit ke kawasan hutan dan gambut maka diperlukan kebijakan untuk menghentikan pembangungan perkebunan kelapa kelapa sawit yang baru. Kebijakan yang telah dilakukan Pemerintah Indonesia saat ini dengan menerbitkan Inpres No.10/2011, Inpres No.6/2013, PP No.71/2014, dan PP No.57/2016. Penelitian (Suwarno et al., 2016) mengkaji efektivitas kebijakan moratorium hutan dalam reorientasi penggunaan lahan di Indonesia.

Pemerintah perlu melakukan penegakan hukum terhadap perkebunan kelapa sawit yang telah terlanjur berada di kawasan hutan dan gambut. Kebijakan Pemerintah untuk mengatasi pendudukan kawasan hutan dan gambut antara lain dengan menerbitkan Permentan No.11/2015 tentang Indonesian Sustainable Palm Oil (ISPO) yang juga telah dilakukan oleh lembaga swasta internasional dengan menerapkan Roundtable on Sustainable Palm Oil (RSPO). Kedua lembaga sertifikasi ini mensyaratkan produksi kelapa sawit berkelanjutan yang tidak menggunakan kawasan hutan dan lahan gambut (Hutabarat, 2017a).

Kegiatan perkebunan kelapa sawit pada areal hutan dan gambut yang telah terlanjur diduduki oleh perkebunan kelapa sawit hendaknya segera dihentikan. Pada kawasan hutan dan gambut tersebut segera dilakukan revitalisasi untuk mengembalikan ekosistem hutan dan gambut di kawasan bekas perkebunan kelapa sawit (Hutabarat, 2018a; Suwarno et al., 2015).

Produksi kelapa sawit hendaknya dilakukan pada lahan-lahan yang telah dialokasikan untuk perkebunan dan sesuai untuk budidaya kelapa sawit. Untuk mengoptimalkan penggunaan lahan-lahan tersebut diperlukan revitalisasi perkebunan yang sudah ada untuk meningkatkan produktivitas sesuai potensi produksi dan teknologi yang telah tersedia pada saat ini (Hutabarat et al., 2018).

\section{KESIMPULAN}

Peningkatan permintaan minyak sawit telah direspon oleh investor dan masyarakat di Indonesia dengan melakukan ekspansi perkebunan kelapa sawit. Namun, pembukaan perkebunan baru utnuk kelapa sawit sering dilakukan tanpa dilengkapi dengan dokumen legalitas seperti sertifikat tanah, Surat Tanda Daftar Usaha Budidaya (STD-B) dan Surat Pernyataan Kesanggupan Pengelolaan Lingkungan (SPPL). Akibatnya, 
pengembangan perkebunan kelapa sawit menjadi liar dan tidak terkontrol. Berdasarkan data yang tersedia terdapat indikasi penggunaan kawasan hutan dan kawasan gambut untuk kegiatan perkebunan kelapa sawit.

Untuk mengoptimalkan penggunaan lahan untuk perekbunan kelapa sawit maka diperlukan strategi dan kebijakan yang mampu mendorong kegiatan perkebunan kelapa sawit yang lestari dan berkelanjutan. Pertama, kebijakan yang menghentikan perluasan atau ekspansi perkebunan kelapa sawit yang baru. Kedua, kebijakan menghentikan kegiatan perkebunan kelapa sawit di kawasan hutan dan gambut yang terlajur digunakan. Ketiga, kebijakan memperbaiki ekosistem dan masalah sosial di kawasan hutan dan gambut bekas perkebunan kelapa sawit. Keempat, kebijakan yang mendorong intensifikasi untuk meningkatkan produktivitas di areal resmi perkebunan kelapa sawit.

\section{UCAPAN TERIMA KASIH}

Tulisan ini dapat direalisasikan bekerja sama dengan Tim Peneliti INREF SUSPENSE Wageningen University, The Netherlands.

\section{DAFTAR PUSTAKA}

Badrun, M. 2010. Lintasan 30 Tahun Pengembangan Kelapa Sawit. Direktorat Jenderal Perkebunan, Kementerian Pertanian Republik Indonesia dan GAPKI, Jakarta. 79p.

BKSDA Riau. 2014. Upaya Pengendalian Kebakaran Hutan di Provinsi Riau Tahun 2014. Balai Besar Konservasi Sumber Daya Alam (BBKSDA), Pekanbaru.

Dinas Lingkungan Hidup dan Kehutanan Provinsi Riau. 2017. Implementasi Rencana Perlindungan dan Pengelolaan Ekosistem Gambut: Optimalisasi Peran Stakeholders dalam Membangun Kesatuan Hidrologi Gambut (KHG) Berkelanjutan di Provinsi Riau. Paper presented at the Pra Workshop Implementasi Rencana Perlindungan dan Pengelolaan Ekosistem Gambut, LPPM Universitas Riau, Pekanbaru.

Dinas Tanaman Pangan Hortikultura dan Perkebunan Provinsi Riau. 2017. Statistik Perkebunan Provinsi Riau 2016. Pekanbaru.

Directorate General of Estate Crop. 2015. Oil Palm. Tree crop estate statistic of Indonesia, 2012-2014. Jakarta: Indonesia Ministry of Agriculture.

Ernaputra, F. 2017. Pengembangan Komoditas Sawit di Riau serta Dukungan Kebijakan. Paper presented at the Seminar Satu Hari Lebih Dekat dengan RSPO 17 January 2017. RSPO, Pekanbaru.

Fairhurst, T.H. 2003. Environmental aspects of fertilizer management in oil palm. Paper in proceedings of the Good Agricultural Practice and Food Safety Management in Palm Oil Industry, 24-25 February 2003. MPOA, Putrajaya, Malaysia: 1-23.

Henderson, J.M., and Quandt, R.E. 1980. Microeconomic Theory: A mathematical approach. (Third edition ed.). Auckland: McGraw-Hill International Book Company.

Hidayat, N.K., A. Offermans, and P. Glasbergen. 2016. On the profitability of sustainability certification certification: An analysis among Indonesian palm oil smallholders. Journal of Economics and Sustainable Development, 7(18): 45-62.

Hutabarat, S. 2017a. Daya Saing Perkebunan Kelapa Sawit Rakyat dan Tuntutan Sertifikasi Produk di Pasar Global. Paper in proceedings of the Seminar Nasional Daya Saing Berkelanjutan Agribisnis Spesifikasi Lokal, 27 Juli 2017. Departmen Sosial Ekonomi Pertanian, Fakultas Pertanian, Universitas Padjadjaran, Jatinangor: 232-237.

Hutabarat, S. 2017b. Tantangan Keberlanjutan Pekebun Kelapa Sawit Rakyat di Kabupaten Pelalawan, Riau dalam Perubahan Perdagangan Global. Masyarakat Indonesia 43(1): 47-64.

Hutabarat, S. 2018a. Balancing Sustainable Agriculture and Economic Profits: Oil palm smallholder challenges toward certification in Riau Province. Paper in proceedings of the Agrifood System International Conference on Agrifood system towards Agriculture 4.0 and delivery of Sustainable Development Goals (SDGs), Padang, West Sumatera, Indonesia.

Hutabarat, S. 2018b. Challenges on peatland restoration: From oil palm plantation to sustainable peatland ecosystem. Paper in proceedings of the International Conference on Natural Resources and Sustainable Development (ICNRSD), 2-3 August 2018. Medan, Indonesia.

Hutabarat, S., Slingerland, M., and Dries, L. 2017. The prospects and challenges of certification for different types of oil palm smallholders. in Progress. 
Hutabarat, S., M. Slingerland, P. Rietberg, and L. Dries. 2018. Costs and benefits of certification of independent oil palm smallholders in Indonesia. International Food and Agribusiness Management Association 21(6): 1-20. https://doi.org/10.22434/IFAMR2016.0162

Jelsma, I., and G.C. Schoneveld. 2016. Towards more sustainable and productive independent oil palm smallholders in Indonesia: Insights from the development of a smallholder typology. Working Paper 210. CIFOR, Bogor, Indonesia.

Komisi ISPO. 2014. Perkebunan Kelapa Sawit Berkelanjutan (Indonesia Sustainable Palm Oil/ISPO): Persyaratan untuk Kebun Petani Swadaya (Draft IV). Jakarta: Sekretariat Komisi ISPO, Direktorat Jenderal Perkebunan, Kementerian Pertanian.

Lee, J.S.H., J. Ghazoul, K. Obidzinski, and L.P. Koh. 2014. Oil palm smallholder yields and incomes constrained by harvesting practices and type of smallholder management in Indonesia. Oil palm smallholder yields and incomes constrained by harvesting practices and type of smallholder management in Indonesia 34(2): 501-513.

Manggabarani, A. 2009a. Memaknai Sebuah Anugrah Sumbangsih Kelapa Sawit Indonesia Bagi Dunia. Jakarta: Ideals Agro Akbar.

Manggabarani, A. 2009b. Palm Oil: A Golden Gift From Indonesia to the World. Directorate General of Estate Crops in Colaboration with Sinar Mas, Jakarta. 102p.

Molenaar, J.W., et al. 2010. Analysis of the Agronomic and Institutional Constraints to Smallholder Yield Improvement in Indonesia. Amsterdam, The Netherlands: Aidenvironment.

Pahan, I. 2012. Panduan Lengkap Kelapa Sawit: Manajemen Agribisnis dari Hulu hingga Hilir (A complete guide on oil palm: Agribusiness management from upstream to downstream). Penerbit Swadaya, Jakarta. pp.411.

PPKS Marihat. 2004. Kelapa Sawit Komoditas Unggulan Indonesia. Paper presented at the Seminar Roundtable Kelapa Sawit, Pekanbaru.

Rahadian, D. 2013. Delivering the Independent Palm Oil Smallholder into Sustainable: The First RSPO Certified for Indonesia Independent Palm Oil Smallholders. Jakarta: WWF.

RSPO. 2007. RSPO Principles and criteria for sustainable palm oil production.

Rumondang, T. 2017. Transforming the market to make sustainable palm oil the norm. Paper presented at the RSPO General Lecture UNRI, 18 January 2017. RSPO, Pekanbaru.

Suwarno, A., L. Hein, and E. Sumarga. 2015. Who Benefits from Ecosystem Services? A Case Study for Central Kalimantan, Indonesia. Environmental Management. https://doi.org/10.1007/s00267-015-0623-9

Suwarno, A., M. van Noordwijk, H.P. Weikard, and D.A. Suyamto. 2016. Effectiveness of forest moratorium policies in reorienting land-use change in Indonesia: a multi-agent model. Migration and Adaptation Strategy for Global Climate Change. In press.

Umar, H. 2003. Studi Kelayakan Bisnis: Teknik Menganalisis Kelayakan Rencana Bisnis Secara Komperhensif. PT. Gramedia Pustaka Utama, Jakarta. 480p. 